\title{
Sheer Magic!
}

\section{Paul Shaw ${ }^{1}$ University of Minnesota}

Anyone interested in hearing the unlikely combination of flute, euphonium and piano must rush out to get Tchaka Mizik, a new CD recorded at Compass Point Studios in Nassau, Bahamas by C Force: Christine, Christian and Christy, respectively.

Christine Gangelhoff's pleasing flute sound, impeccable phrasing, and energetic delivery throughout is enough to recommend the disc. Particularly noteworthy is the spell she casts in C Force's own arrangement of the haunting Chanson Folklorique d'Haiti, Invocation a Dambala by Werner A. Jaegerhuber (1900-1953). Ms. Gangelhoff's technical stamina and well-gauged sense of the French Rhapsodic style in Tangente Au Yanvalou by Haitian Julio Racine (b. 1945) is also worthy of special mention. Thanks in no small part to the virtuosity of pianist Christy Lee, this work as well as the duo's performance is the artistic high point of the entire recording.

The oddity of euphonium in the midst of flute and piano is immediately dispelled when one listens to Christian Justilien (b. 1960). His warm tone, nimble technique and astute consideration of ensemble balance allows the first three selections to ... well, sing!

If anything, the true novelty of this artistic project is that the $\mathrm{CD}$ begins with Western European opera duets and ends with Mr. Justilien's Tilla, an original composition cast in the goombay style of his native Bahamas. C Force adeptly makes the connection from Europe to The Bahamas in a musical flow chart, starting with popular Italian opera-Verdi's La Traviata; following with French opera in famous duets from Bizet's Les pêcheurs de perles and Delibes' Lakmé; then proceeding to the French Caribbean islands of Guadeloupe with a benign Sonata in early classical style written for flute and piano by Joseph Boulogne (1739-1799), and Haiti, in which the last of four selections-a C Force arrangement of Ludovic Lamothe's méringue, Nibo, draws on the culture of the African Diaspora. And so, the trio leads us, finally, to their Bahamian home-Christine's remarkably authentic “fife" playing, Christy's rhythmic groove at the keyboard, Christian's Caribbean swing and creative ambience, and of course, the goombay. But who was the mystery percussion player (or players)?

Speaking of mystery, for a brief moment the first track on the disc exposes a piano, shall we say, with less than optimal tone quality, especially in the register immediately above Middle C. That Christy Lee and Terry Manning - the former with pure pianistic and arranging talent, and the latter with consummate recording and "sweetening" skills, perhaps-could produce, master and engineer so satisfying a disc musically and, for the most part, tonally, given the ghastly instrument with which they had to work, will remain a mystery to this reviewer. All one can say is that the end result is sheer magic! For this alone, $\mathrm{C}$ Force is worth following all the way home to The Bahamas.

The recording of the CD was made possible through a grant from The College of The Bahamas. - Ed.

\footnotetext{
${ }^{1}$ Paul Shaw, Associate Professor, School of Music, University of Minnesota, 2106 Fourth Street South, Minneapolis, MN 55455, USA

e-mail: shawx004@umn.edu

How to cite this article in APA style ( ${ }^{\text {th }}$ ed.): Shaw, P. (2010). Sheer magic [Review of the CD Tchaka Mizik]. The International Journal of Bahamian Studies, 16, 106. https://doi.org/10.15362/ijbs.v16i0.132
}

(CP. Shaw, 2010. Journal compilation @ The International Journal of Bahamian Studies, 2010. 